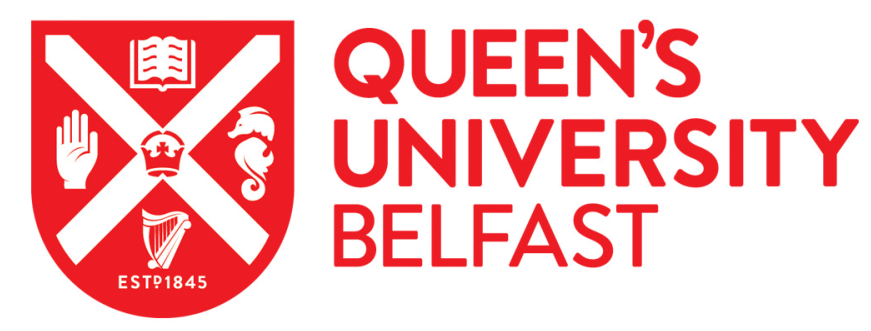

\title{
Neolithic settlement at the woodland's edge: palynological data and timber architecture in Orkney, Scotland
}

Farrell, M., Bunting, M. J., Lee, D. H. J., \& Thomas, A. (2014). Neolithic settlement at the woodland's edge: palynological data and timber architecture in Orkney, Scotland. Journal of Archaeological Science, 51, 225-236. https://doi.org/10.1016/j.jas.2012.05.042

Published in:

Journal of Archaeological Science

Document Version:

Peer reviewed version

Queen's University Belfast - Research Portal:

Link to publication record in Queen's University Belfast Research Portal

Publisher rights

(C) 2014 Elsevier. This manuscript version is made available under the CC-BY-NC-ND 4.0 license (http://creativecommons.org/licenses/bync-nd/4.0/), which permits distribution and reproduction for non-commercial purposes, provided the author and source are cited.

\section{General rights}

Copyright for the publications made accessible via the Queen's University Belfast Research Portal is retained by the author(s) and / or other copyright owners and it is a condition of accessing these publications that users recognise and abide by the legal requirements associated with these rights.

Take down policy

The Research Portal is Queen's institutional repository that provides access to Queen's research output. Every effort has been made to ensure that content in the Research Portal does not infringe any person's rights, or applicable UK laws. If you discover content in the Research Portal that you believe breaches copyright or violates any law, please contact openaccess@qub.ac.uk. 


\title{
Neolithic settlement at the woodland's edge: palynological data and timber architecture in Orkney, Scotland
}

\author{
Michelle Farrell ${ }^{a,}$, M. Jane Bunting ${ }^{\mathrm{a}}$, Daniel H.J. Lee ${ }^{\mathrm{b}}$, Antonia Thomas ${ }^{\mathrm{b}}$ \\ a Department of Geography, University of Hull, Cottingham Road, Hull, HU6 7RX, UK \\ m.farrell@hull.ac.uk \\ m.j.bunting@hull.ac.uk
}

\author{
${ }^{\mathrm{b}}$ Archaeology Department, University of the Highlands and Islands, Orkney College, East \\ Road, Kirkwall, KW15 1LX, UK \\ daniel.lee@orkney.uhi.ac.uk \\ antonia.thomas@orkney.uhi.ac.uk
}

*Tel.: +44 1482 465578; fax: +44 1482 466340; email: m.farrell@hull.ac.uk

\begin{abstract}
It has often been assumed that the islands of Orkney were essentially treeless throughout much of the Holocene, with any 'scrub' woodland having been destroyed by Neolithic farming communities by around $3500 \mathrm{cal}$. BC. This apparently open, hyper-oceanic environment would presumably have provided quite marginal conditions for human settlement, yet Neolithic communities flourished and the islands contain some of the most spectacular remains of this period in north-west Europe. The study of new Orcadian pollen sequences, in conjunction with the synthesis of existing data, indicates that the timing of woodland decline was not synchronous across the archipelago, beginning in the Mesolithic, and that in some areas woodland persisted into the Bronze Age. There is also evidence to suggest that woodland communities in Orkney were more diverse, and therefore that a wider range of resources was available to Neolithic people, than has previously been assumed. Recent archaeological investigations have revealed evidence for timber buildings at early Neolithic settlement sites, suggesting that the predominance of stone architecture in Neolithic Orkney may not have been due to a lack of timber as has been supposed. Rather than simply reflecting adaptation to resource constraints, the
\end{abstract}


Farrell et al 2014 Journal of Archaeological Science DOI 10.1016/j.jas.2012.05.042

reasons behind the shift from timber to stone construction are more complex and encompass social, cultural and environmental factors.

Keywords: archaeology, Neolithic, Orkney, pollen analysis, woodland

\section{Introduction}

The Neolithic stone monuments of Orkney (Fig. 1) are amongst some of the best preserved and most intensively studied in the world. The islands today are largely treeless, and there is a long-held assumption that native woodland during the Neolithic was insufficient to provide suitable structural timbers, resulting in Orkney's predominance of stone architecture (Ritchie, 1985). In this paper we explore the extent to which this assumption is still valid in the light of accumulating palaeoecological data (see Fig. 1a for site locations), alongside evidence from a recently excavated early Neolithic settlement at the Braes of Ha'Breck, Wyre (Fig. 1b).

\section{FIGURE 1 NEAR HERE}

Palaeoecological records imply that Orkney once had quite extensive tree cover, mostly represented by high percentages of Betula (birch) and Corylus avellana-type (hazel) pollen which have led this to be dismissed as 'scrub' or 'shrubland' rather than true woodland (Davidson et al., 1976; Keatinge and Dickson, 1979; Moar, 1969). The narrative of Holocene environmental change developed in the work of Moar (1969) and Keatinge and Dickson (1979) informed later studies of Orcadian archaeology (e.g. Renfrew, 1985; Richards, 2005; Ritchie, 1995). This narrative states that the islands were covered with birch-hazel 'scrub' woodland during the Mesolithic which was then almost entirely cleared for agriculture within at most a few hundred years at the onset of the Neolithic (Davidson and Jones, 1985; Dickson, 2000; Tipping, 1994), forcing the islanders to turn to the readily available flagstone for all their building materials.

Two problems with the evidence underlying this narrative concern dating of palaeoecological sequences and the nature of the woodland. Moar's (1969) profiles are 
Farrell et al 2014 Journal of Archaeological Science DOI 10.1016/j.jas.2012.05.042

dated on the basis of biostratigraphy, and radiocarbon dates on one of Keatinge and Dickson's (1979) cores are uncertain due to the 'hard water effect'. Bunting (1994) also worked on carbonate-rich cores in west Mainland and constructed a possible chronology using biostratigraphy and a single early Holocene tephra layer, but additional analyses suggest that both sites have a hiatus in the mid-Holocene (K.J. Edwards, pers. comm.; O'Connor and Bunting, 2009) so the age models must be abandoned.

The woodlands that developed in Orkney seem, at least in less exposed areas, to have been dense-canopied true woodland rather than 'scrub' (Bunting, 1994). Pollen types from tree species such as Quercus (oak) and Pinus sylvestris (pine) are consistently recorded, but it was initially assumed that these originated from trees growing on the Scottish mainland (e.g. Keatinge and Dickson, 1979; Moar, 1969). More recent studies (Bunting, 1994; de la Vega-Leinert et al., 2007) argue that these and other species were present in the early Holocene Orcadian woodlands.

The Neolithic in Scotland is defined by Edwards and Ralston (2003) as the period $c$. 4000-2000 cal. BC), and the transition from early to late Neolithic in Orkney is usually taken as c. $3000 \mathrm{cal}$. BC (Card, 2005). These definitions are used to frame the discussion of early and late Neolithic throughout this paper. Until recently, the only early Neolithic house known in Orkney was that at the Knap of Howar in Papa Westray (Ritchie, 1983; Traill and Kirkness, 1937). Built in stone but contemporary with the early Neolithic timber houses found elsewhere in Scotland during the 4th millennium BC, it appeared to support the argument that the wealth of Neolithic stone buildings in Orkney was a consequence of a lack of timber. However, many other early Neolithic buildings have now been identified in Orkney (Fig. 1b), including those at Howe, near Stromness (Ballin Smith, 1994); Pool, Sanday (Hunter, 2007); Green, Eday (Miles, 2010; Miles, 2008); Stonehall, Firth (Richards et al., 2001, Richards and Jones, forthcoming); the Knowes of Trotty, Harray (Card et al., 2006, Downes, forthcoming); Wideford, St Ola (Richards, 2003; Richards and Jones, forthcoming,); and the Braes of Ha'Breck, Wyre (Thomas and Lee, 2010; Thomas and Lee, 2008; Lee and Thomas, forthcoming; Lee and Thomas, in prep.). A wide variety of different building styles are now known to occur during this 
period, demonstrating that early Neolithic settlement in the islands was more complex than previously thought. At two of these sites, Wideford and Wyre, both timber and stone buildings have been discovered.

The discovery of timber structures at Wideford was extremely significant (Richards, 2003), providing the first evidence for such buildings in Orkney at a time when stone architecture appears to predominate. The Wideford excavations are not yet published and will not be discussed here; however, similar remains have recently been excavated during the on-going excavations on Wyre by two of the authors (Lee and Thomas, in prep). These will be explored in more detail below. At both sites the superimposition of a stone building on the remains of a timber structure seems to evidence a transition from wood to stone architecture in the second half of the $4^{\text {th }}$ millennium BC, a time of dramatic social and, it is often assumed, environmental transformations in Orkney.

This paper uses palaeoecological data to assess whether changing resource availability constrained the choice of building material in the development of Orcadian Neolithic domestic architecture, using a combination of newly obtained palaeoecological sequences (Farrell, 2009) and a reassessment of previously published pollen data from sites with multiple reliable radiocarbon age estimates. The early Neolithic settlement on Wyre, which is currently the focus of on-going excavations, is used as a case study to demonstrate the complexity of timber and stone use in domestic architecture.

\section{Methods}

Palaeoecological methods used for the collection of new pollen records by Farrell (2009) are briefly described. In order to synthesise pollen records from various published sources, we then identify common criteria for interpretation of the woodland pollen signal.

\subsection{Field methods}

Sedimentary basins of 100-500 m diameter were sought since basins of this size are thought to recruit most of their pollen from an area within 300-800 m (Sugita, 1994). At 
Farrell et al 2014 Journal of Archaeological Science DOI 10.1016/j.jas.2012.05.042

each identified site (Farrell, 2009) a programme of survey coring was carried out using a Dutch auger. The deepest and most complete sequence of deposits located was sampled for laboratory analysis using a $5 \mathrm{~cm}$ diameter Russian sampler (Jowsey, 1966). All samples were wrapped in clingfilm and aluminium foil in the field and on return to the laboratory were stored in the dark at $5{ }^{\circ} \mathrm{C}$.

\subsection{Laboratory methods}

All sequences were described according to Troels-Smith (1955). One $\mathrm{cm}^{3}$ subsamples were prepared for pollen analysis following standard procedures (Moore et al., 1991), including treatment with hot $40 \%$ hydrofluoric acid, $5 \%$ sodium pyrophosphate and fine sieving as appropriate to remove mineral components. Pollen concentrations were established by adding a known concentration of Lycopodium clavatum spores to the samples before treatment (Stockmarr, 1971). Residues were stained using aqueous safranin and mounted on microscope slides in silicon oil, then counted at a magnification of $\times 400$, with $\times 1000$ magnification and oil immersion used for critical identifications. A minimum of 300 terrestrial pollen grains and spores were counted per sample (Maher, 1972). Pollen and spores were identified using the keys of Moore et al. (1991) and Beug (2004) and the reference collections of the Department of Geography, University of Hull. Pollen taxonomy follows Bennett (1995). Percentage and concentration diagrams were plotted using psimpoll 4.25 (Bennett, 2005). Numerical zonation of the diagrams based on optimal splitting by sums-of-squares was carried out using a function of psimpoll 4.25 (Bennett, 2005) on a subset of the pollen data containing all main sum taxa that constituted $2 \%$ or more of at least one sample.

Selected non-pollen palynomorphs (NPPs) were identified with reference to van Geel (2001; 1978) and van Geel et al. $(2003 ; 1989 ; 1983 ; 1981)$, recorded during pollen counting and plotted as percentages of the combined sum of total land pollen and spores plus NPPs (Mighall et al., 2006). The microscopic charcoal content of samples was estimated using the point count method (Clark, 1982). The concentration of microscopic charcoal $\left(\mathrm{cm}^{2} \mathrm{~cm}^{-3}\right)$ and the ratio of this to pollen concentration (Bennett et al., 1990a) are plotted on the percentage pollen diagram. 
Farrell et al 2014 Journal of Archaeological Science DOI 10.1016/j.jas.2012.05.042

Samples relating to distinct changes in arboreal pollen percentages were submitted for AMS radiocarbon measurements to SUERC laboratories, East Kilbride and the

${ }^{14}$ CHRONO Centre, Belfast. Age estimates were calibrated using CALIB 5.1 (Stuiver and Reimer, 1993).

\subsection{Data analysis}

Various age models were tested for all new sequences (Farrell, 2009) but in the absence of a large number of age estimates none was found to give any advantage over simple linear interpolation between and extrapolation from age estimates. Radiocarbon age estimates from existing Orcadian palaeoecological sequences were calibrated using CALIB 5.1 (Stuiver and Reimer, 1993) and new age models were constructed using linear interpolation between and extrapolation from these age estimates so that timing of events was derived using the same methodology.

In order to draw together evidence for the timing and extent of woodland loss, it is necessary to adopt a standard method of identifying changes in woodland cover and decline events in the pollen record. Analysis of modern Orcadian pollen samples has shown that the landscape today, containing some plantations but minimal semi-natural woodland, is represented by arboreal pollen percentages of $c .10 \%$ (Bunting, 1996). In north-west Scotland arboreal pollen frequencies of less than $20 \%$ can occur within a few hundred metres of substantial mature woodland stands in a predominantly open landscape (Bunting, 2002). 20\% arboreal pollen is therefore taken as a threshold for an open landscape with occasional woodland stands, whilst $>50 \%$ arboreal pollen is interpreted as a wooded landscape with some open areas. Woodland decline events were categorised as follows. Primary declines are defined as those where arboreal pollen percentages were originally above $50 \%$ and decrease by more than $20 \%$ over $1-2$ samples. Exceptions to this are made in the cases of Loch of Knitchen and Loch of Torness (Bunting, 1996), where woodland was never extensive; declines at these sites are also considered as primary. Secondary declines were identified where arboreal pollen percentages were originally $50 \%$ or below and declined further to $20 \%$ or less. 
Farrell et al 2014 Journal of Archaeological Science DOI 10.1016/j.jas.2012.05.042

\section{Results}

Results from one new site, Blows Moss, are presented here in detail as an example of the data available. This is the longest of the new records and the pollen data reflects the sequence of establishment, disturbance and eventual loss of woodland on the island of South Ronaldsay, an area for which very little palaeoecological data is currently available. Details of the records from Hobbister and Whaness Burn are given in Farrell (2009).

Blows Moss (NGR ND 455860) is a large (approximately 30 ha) elongate wetland on South Ronaldsay (Fig. 1a). At present the wetland is a basin mire supporting fen vegetation. Species present include Caltha palustris (marsh-marigold), Filipendula ulmaria (meadowsweet), Equisetum palustre (marsh horsetail), Mentha aquatica (water mint), Menyanthes trifoliata (bogbean) and Poaceae (grasses). The sequence studied ends at a depth of $6.5 \mathrm{~m}$, the point at which the sediment became too difficult to recover.

\subsection{Age estimates}

Table 1 shows the age estimates obtained from the Blows Moss core. Assuming constant sediment accumulation in the lower part of the core the base of the recovered sequence has an approximate age of $7970 \mathrm{cal}$. BC.

\section{TABLE 1 NEAR HERE}

\subsection{Mid-Holocene woodland dynamics around Blows Moss}

Summary pollen and spore percentage and concentration diagrams for the period $c .8000$ cal. BC to c. 3300 cal. BC are presented in Fig. 2; for full diagrams see Farrell (2009). Local pollen assemblage zones are summarised in Table 2.

FIGURE 2 NEAR HERE

TABLE 2 NEAR HERE 
Farrell et al 2014 Journal of Archaeological Science DOI 10.1016/j.jas.2012.05.042

At 8000 cal. BC arboreal pollen made up around $40 \%$ of the total pollen sum. Betula and Salix (willow) pollen occur at frequencies of c. $25 \%$ and c. $3 \%$ respectively, suggesting that patchy birch-willow woodland was present in the surrounding landscape. Corylus avellana seems to have become a significant component of the woodland at $c .7850 \mathrm{cal}$. $\mathrm{BC}$, and birch-hazel woodland reached its fullest extent by c. $7400 \mathrm{cal}$. BC, when arboreal pollen percentages reach $80 \%$. This is comparable to the record from Scapa Bay in central Mainland (de la Vega-Leinert et al., 2007), where birch-hazel woodland was established by c. 7450 cal. BC.

Arboreal pollen percentages drop to around $50 \%$ of the total at $c .7210 \mathrm{cal}$. BC, then increase at $c .6480$ cal. BC to $c .70 \%$ of the total pollen sum, suggesting that the woodland canopy became less extensive around the basin for a few hundred years. During this period of reduced arboreal pollen percentages, frequencies of herbaceous taxa increase to $c .25 \%$. Similar episodes of woodland disturbance are seen in pollen records from Quoyloo Meadow in west Mainland (Bunting, 1994) and Keith's Peat Bank on Hoy (Blackford et al., 1996). Pollen assemblages from the post-6500 cal. BC woodland at Blows Moss have slightly increased Quercus pollen frequencies, suggesting that oak may have become a component of the woodland.

Primary woodland decline in the Blows Moss pollen record occurs at the end of LPAZ BM-1 (c. 5390 cal. BC), when arboreal pollen percentages decrease to around $30 \%$. The earliest radiocarbon dates for Mesolithic occupation in Orkney are from complex structural evidence at Links House, Stronsay, c. 7050-6650 cal BC (Woodward, 2012; Lee and Woodward, in prep; Woodward, Lee and Wickham-Jones, in prep.) and from Long Howe, East Mainland, c. 6740 cal. BC (Robertson and Woodward, 2007). These sites demonstrate an established Mesolithic population throughout the archipelago from at least c. $7000 \mathrm{cal} \mathrm{BC}$. As yet, there is no artefactual evidence for Mesolithic occupation in South Ronaldsay. The continuous presence of microscopic charcoal in the record from Blows Moss suggests that humans were present in the area during the Mesolithic (Bennett et al., 1990a), but charcoal concentration during the period of reduced arboreal pollen percentages does not increase which suggests that they were not responsible for 
this brief opening up of the woodland canopy. The coincidence of woodland decline with a change from lake to fen conditions is similar to records from other sites, where it has been suggested that the hydroseral transition may have been initiated by increased erosion as a consequence of woodland decline (Bunting, 1994). The change from open water to fen conditions at Blows Moss probably reduced the relevant source area of pollen of the site, meaning that following this event the pollen assemblages became increasingly dominated by local taxa such as Cyperaceae (sedges). This may partially account for the reduction in arboreal pollen percentages, although with a decline of around $40 \%$ it is also likely that there was some actual loss of woodland cover around the site. Following the primary decline, arboreal pollen percentages of $c .30 \%$ suggest that some woodland was still present within the wider landscape (Bunting, 2002). The occurrence of two Betula seeds and unidentified wood fragments in the sediment core at c. $4950 \mathrm{cal}$. BC indicates that birch and possibly other tree species were present fairly close to the sampling site (Farrell, 2009).

This reduced woodland cover seems to have persisted until c. $3610 \mathrm{cal}$. BC, when arboreal pollen percentages decline further to around $10 \%$ of the total pollen sum and remain between 10 and $20 \%$ until the end of the sequence presented here at $c .3290 \mathrm{cal}$. $\mathrm{BC}$ in the early Neolithic. At the time of this secondary woodland decline several indicators of anthropogenic activity are present, including peaks in microscopic charcoal and low frequencies of the pollen of anthropogenic indicator species (Behre, 1981) including Plantago lanceolata (ribwort plantain), Rumex undiff. (docks) and Artemisiatype (mugwort) which suggests that pastoral farming was taking place. Further evidence for grazing is provided by the presence of coprophilous fungal spores (Fig. 2, Table 2). The decrease in arboreal pollen percentages is also associated with a change in sediment type from well-humified peat to a more herbaceous peat, perhaps indicating an increase in wetness at the site. This change in hydrological conditions may have been a contributing factor in the loss of woodland, although it is also possible that the decline in tree cover contributed to increased waterlogging by allowing greater infiltration of precipitation. These data suggest that the main cause of woodland loss was probably anthropogenic activity, although hydrological changes may also have contributed. 
Farrell et al 2014 Journal of Archaeological Science DOI 10.1016/j.jas.2012.05.042

\subsection{Review of other palaeoecological data}

Four sites show evidence for temporary woodland disturbance in the form of reduced arboreal pollen percentages and corresponding increases in pollen of herbaceous taxa during the Mesolithic period. At Keith's Peat Bank (Blackford et al., 1996) and Quoyloo Meadow (Bunting, 1994) this was attributed to anthropogenic activities linked to the improvement of hunting opportunities, but at Blows Moss and Spretta Meadow (Farrell, unpublished data) the cause could equally well have been natural processes. Following these disturbances woodland apparently recovered at all four sites, demonstrating a certain degree of resilience within the natural system.

The estimated ages of primary and secondary woodland declines from unpublished and published sites are shown in Fig. 3. The general assumption that woodland decline in Orkney occurred at c. 3500 cal. BC (Davidson and Jones, 1985; Dickson, 2000; Tipping, 1994), with most woodland loss attributed to Neolithic agriculture, is clearly not supported. Woodland decline occurs at different times in different locations, implying that the causes were complex and included both local and regional drivers of environmental change. At several sites, woodland loss occurred in multiple stages, and some woodland persisted into the Bronze Age.

\section{FIGURE 3 NEAR HERE}

Substantial pre-Neolithic loss of woodland occurred at several sites, most of which show distinct primary and secondary decline events. At the Bay of Skaill (de la Vega-Leinert et al., 2000) and Spretta Meadow (Farrell, unpublished data) in west Mainland, primary woodland declines occurred at c. $5500 \mathrm{cal}$. BC. A secondary decline took place around Bay of Skaill at c. 4290 cal. BC. At Hobbister in central Mainland, secondary woodland decline occurred over approximately 600 years from $c .4760 \mathrm{cal}$. BC. There is no clear evidence for human disturbance, and the extended period of time over which woodland loss occurred along with evidence for a slight increase in mire surface wetness, suggest 
Farrell et al 2014 Journal of Archaeological Science DOI 10.1016/j.jas.2012.05.042

that the main cause of woodland decline at Hobbister was probably a change in local hydrological conditions (Farrell, 2009).

At Loch of Torness on Hoy, woodland cover was never extensive and seems to have largely disappeared by $c .4850$ cal. BC. Woodland at Loch of Knitchen on Rousay was similarly sparse, and primary woodland decline here is radiocarbon dated to c. $4150 \mathrm{cal}$. BC (Bunting, 1996). Changes in climate and local hydrological conditions are invoked as the cause of woodland loss at both sites, although small-scale human activity may also have contributed (Bunting, 1996).

At Spretta Meadow a secondary woodland decline occurred at the onset of the Neolithic period (Farrell, unpublished data), supporting the argument that the dating of other primary west Mainland declines, which apparently occurred around 500 years later (Bunting, 1994; Keatinge and Dickson, 1979), is flawed. Primary woodland decline at Scapa Bay in central Mainland took place around the same time and coincided with the first signs of pastoral vegetation communities, suggesting that the cause was principally anthropogenic (de la Vega-Leinert et al., 2007). Secondary woodland decline at Glims Moss in west Mainland (Keatinge and Dickson, 1979) took place at c. $3500 \mathrm{cal}$. BC, around the same time as secondary decline at Scapa Bay (de la Vega-Leinert et al., 2007).

There is evidence for the presence of small stands of birch-hazel woodland in the landscape around Whaness Burn on Hoy at the time of the early-late Neolithic transition (Farrell, 2009). Pine woodland is hypothesised to have been present around this site during the late Neolithic, with the decline of this community in the early Bronze Age apparently caused by climatic deterioration, perhaps in combination with deliberate clearance by people (Farrell, 2009).

There can be problems with the detection of woodland in a predominantly open landscape by pollen records (Bunting, 2002). An Orcadian example is provided by two cores from Hobbister, which show different dates for secondary woodland decline (Farrell, 2009). This is interpreted as the survival of a substantial stand of woodland close 
to the second coring point which was not detected at the first. This woodland survived even as peat was spreading in the immediate vicinity and as the surrounding area was becoming increasingly open and utilised for agriculture. The apparent loss of this woodland in the late Neolithic is associated with several indicators of anthropogenic activity, suggesting that the cause was largely either deliberate clearance or the introduction of grazing animals which would have inhibited natural regeneration (Farrell, 2009). Secondary woodland decline also took place at Loch of Knitchen on Rousay during the late Neolithic, at c. 2700 cal. BC (Bunting, 1996). Tisdall et al. (in prep.) argue for the presence of open Corylus woodland at Mill Bay, Stronsay at around the time of the Neolithic to Bronze Age transition.

Following the decline of woodland in Orkney, palaeoecological evidence indicates an open, largely treeless landscape for the remainder of the Holocene (Bunting, 1994; Jones, 1979; Keatinge and Dickson, 1979). Some small stands of birch-hazel woodland were present during the Bronze Age, for example in the west Mainland hills (Keatinge and Dickson, 1979), at Lesliedale Moss (Jones, 1979) and on South Ronaldsay (Bartlett, 1983; Farrell, 2009; Jones, 1975). Pollen evidence for the presence of woodland in west Mainland during the Bronze Age is supported by the recovery of birch charcoal from a Bronze Age barrow at Mousland which was interpreted as being of local origin (Downes et al., 1994). There are clearly problems with the detection of patches of woodland in a predominantly open landscape, as demonstrated at Hobbister (Farrell, 2009), and the extent of woodland in later prehistory may have been substantially underestimated.

As discussed above, the description of Orcadian woodland as 'birch-hazel scrub' has been challenged, with Bunting (1994) inferring local growth of pine and oak around Quoyloo Meadow and de la Vega-Leinert et al. (2007) suggesting the presence of local stands of oak at Scapa Bay. Additional evidence for the growth of pine now includes records from Hobbister in Orphir and Whaness Burn on Hoy (Farrell, 2009), and for oak comes from Blows Moss (Fig. 2) and Spretta Meadow (Farrell, unpublished data). Alnus glutinosa (alder) was apparently locally abundant around Hobbister towards the end of the late Neolithic (Farrell, 2009). 


\subsection{Recent excavations at the Braes of Ha'Breck, Wyre}

Until recently, there was little available evidence for the exploitation of wood during the Neolithic in Orkney, and the small numbers of timbers in otherwise stone houses such as the Knap of Howar had been explained as derived from driftwood (e.g. Ritchie, 1983). Whilst the sea would have undeniably always provided some source of building materials for these island communities (Dickson, 1992), the palynological evidence clearly now indicates that timber from local woodland could have provided a more reliable resource. The recent dramatic increase in known early Neolithic sites in Orkney allows a reassessment of wood exploitation in the archaeological record. There is clear evidence for buildings which were predominantly constructed from wood, suggesting a deliberate choice of materials.

The on-going excavations at the Braes of Ha'Breck, Wyre (Fig. 1b) are providing key additional evidence for Neolithic timber architecture in Orkney. Five dwellings have been discovered (Fig. 4) with associated middens and working floors, and a small domestic stone quarry (Thomas and Lee, in prep). The buildings date to the second half of the $4^{\text {th }}$ millennium (ibid.) or the early Neolithic, and are thus broadly contemporary with some of the timber structures at Wideford (Ashmore, 2005). The Wyre structures appear to show an overall transition from wood to stone both through replacement on the same building footprint (Houses 1 and 2), and through stratigraphically overlying but physically adjacent construction (Houses 3 and 4). Nevertheless, some phases of stone building may have been in contemporary use with timber structures, and timbers also continued to be used in the later stone buildings.

\section{FIGURE 4 NEAR HERE}

House 4 (Trench A), comprises at least 14 post-holes averaging $25 \mathrm{~cm}$ in diameter, forming a NNW/SSE oriented rectangular structure around a central scoop hearth. The post-holes in the central area form a linear arrangement projecting into the interior, mirroring the central orthostats which project into the internal space in the stone 
Farrell et al 2014 Journal of Archaeological Science DOI 10.1016/j.jas.2012.05.042

buildings on the site. The overall impression is of a building that was occupied for only a limited period of time; there is very little evidence of re-working of post-holes, pottery was trampled directly into the glacial till floor around the hearth and there were no occupation deposits. When the building was no longer required, the corner posts were removed and their holes filled by large stones; by contrast, the two central post-holes retained their original packers and form, and the timbers were possibly left to rot in situ.

A similar post-built structure, House 1, was identified in Trench C. Its occupation was also short-lived, and its timbers were removed prior to its replacement on the same footprint with a stone-built rectangular house (House 2). Just as the earlier timber-built phase incorporated elements of stone architecture, such as hearth stones, the later predominantly stone-built phase included timber elements such as an axial post, which was left to rot in situ after the building fell out of use.

House 3, immediately to the west of House 4, is a rectangular stone-built structure similar in plan to the houses at Knap of Howar (Ritchie, 1983), Howe (Ballin Smith, 1994) and Knowes of Trotty (Card et al., 2006). Two central wooden posts in the northern end of the building must have been substantial enough to support the roof, and were reworked four or five times, indicating the longevity of occupation in this structure. As in House 2, the latest of these axial posts was left to rot in situ after the rest of the stone building had been dismantled.

In its later phases, a further stone-built dwelling, House 5, was appended to the south of House 3. Whilst this later modification clearly post-dates the timber structure of House 4, certain stratigraphic relationships also suggest that the earlier phase of House 3 may in fact have been contemporary with the occupation of the timber building. Both Houses 3 and 5 were dismantled within the early Neolithic.

A small domestic quarry on the site (Trench E) provides the likely source of the building stone for Houses 2, 3 and 5. One of the earliest fills contained birch round-wood charcoal which has been radiocarbon dated to the mid $4^{\text {th }}$ millennium $\mathrm{BC}$ and indicates that the 
Farrell et al 2014 Journal of Archaeological Science DOI 10.1016/j.jas.2012.05.042

Wyre farmers were exploiting this stone source at the same time as building houses in wood. Some of the upper layers have been dated to the end of the $3^{\text {rd }}$ millennium $\mathrm{BC}$ or the very end of the Orcadian Neolithic. The quarry was therefore backfilled over a period of some 1500 years, during the very time that many narratives suggest that people were turning to flagstone as a substitute for timber. The sequence of building in wood and stone on the site does not therefore coincide with traditional models of woodland decline. This suggests that the choice of building material was far more nuanced than a simple transition from wood to stone.

\section{Discussion}

It is clear from the above review that a wide range of woodland resources are likely to have been available to the Neolithic population of Orkney. Woodland seems to have reached its maximum diversity prior to the Neolithic, with birch, hazel, rowan, willow, oak and pine all argued to have been components of the woodland in the preceding Mesolithic (Bunting, 1994; Farrell, 2009; Tisdall et al., in prep.; de la Vega-Leinert et al., 2007). Recent palaeoenvironmental studies in the Outer Hebrides, also assumed to have supported treeless, uniform environments for much of the Holocene, have revealed evidence for the local presence of several tree species (Ashmore et al., 2000; Bennett et al., 1990b; Fossitt, 1996), and there is no reason why Orkney should not have supported similarly diverse woodland habitats. Wood was clearly available throughout the entire Neolithic period, both as a local resource and as driftwood (Dickson, 1992), providing sufficient timbers for building at Wideford (Richards, 2003) and Braes of Ha'Breck.

Orkney's woodland has often been dismissed as 'birch-hazel scrub' or 'shrubland' rather than true woodland (Davidson et al., 1976; Keatinge and Dickson, 1979; Moar, 1969), but even birch-hazel canopied woodland can be a useful and rich resource. In the North Atlantic region management of birch woodland has been identified as one of the most important issues in the Norse and medieval periods (Church et al., 2007). Birch wood was used as both domestic fuel (Simpson et al., 2003) and to produce charcoal for iron smelting (Church et al., 2007). There is pollen evidence from Greenland to suggest that birch woodland was being managed sustainably (Schofield and Edwards, 2011), 
Farrell et al 2014 Journal of Archaeological Science DOI 10.1016/j.jas.2012.05.042

indicating the importance of this resource to Norse settlers. There is also evidence for coppice management of woodland in Iceland (Church et al., 2007), and that access to wood was being controlled (Simpson et al., 2003). Woodland management was also practised throughout prehistory, with evidence for coppice management of hazel during the Mesolithic provided by fish traps from Ireland (McQuade and O’Donnell, 2007) and Denmark (Christensen, 1997). There is no reason why the birch-hazel woodland of prehistoric Orkney should not have been similarly valued. Greater diversity in some areas would only have increased the range of possible uses and value of the resource.

There are several problems with Orcadian palaeoecological records, including unreliable dating (Bunting, 1994; Keatinge and Dickson, 1979), a lack of or low numbers of age estimates on some sequences (Farrell, 2009; Moar, 1969), hydroseral succession within a site leading to changes in the area of the wider landscape recorded by the pollen record (Bunting, 1994; Farrell, 2009), detection of woodland remnants in a predominantly open landscape (Bunting, 2002; Farrell, 2009) and potential hiatuses in sediment accumulation at some sites (K.J. Edwards, pers. comm.; O’Connor and Bunting, 2009). The high degree of heterogeneity of the prehistoric environment demonstrated here suggests that more records are needed to obtain an accurate picture of woodland history. In comparison with Shetland and the Outer Hebrides, Orkney has relatively few lochs, and those that are present are relatively shallow (Berry, 2000) so do not tend to accumulate deep sediments suitable for palaeoecological reconstruction over long timescales. However survey work on several wetlands, including valley mires, fens and areas of blanket peat has demonstrated that many potential records are available (Farrell, 2009).

Despite these problems, it is clear that the simple model of Orcadian environmental change that has been incorporated into discussions of the islands' archaeology (e.g. Renfrew, 1985; Richards, 2005; Ritchie, 1995) is an over-simplification of the situation. The data presented here suggest that woodland decline did not occur synchronously, and was not all contemporaneous with the onset of the Neolithic. The variations in timing of this event suggest that rather than having one simple regional cause, such as climate change or agricultural activity, it was in fact the result of complex interactions between 
local climatic conditions with pedological and anthropogenic which varied between sites. The recovery of woodland following Mesolithic disturbance at some sites suggests a certain degree of resilience within the natural system. This is supported by evidence for the persistence of stands of trees in the landscape following major woodland decline at several sites, and it seems that the prehistoric Orcadian landscape may not have been as sensitive to changes in environmental conditions as previously assumed.

Moreover, recent archaeological evidence indicates that there was far more subtlety and variability to the choice of architectural materials in the early Neolithic than first appears. The evidence from the Braes of Ha'Breck suggests that whilst in some cases timber buildings were directly replaced with stone structures, others may have been contemporary with them. Despite the apparent supremacy of stone architecture in these later phases, the stone-built dwellings on the site continued to use, and periodically replace, large structural timbers. In some instances key timber elements of the predominantly stone-built phases appear to have been allowed to decay slowly whilst the stone elements of the same structures were dismantled shortly after the buildings went out of use. The building stone quarry at the Braes of Ha'Breck also appears to have a lifecycle, perhaps linked to that of the houses, and was exploited and carefully backfilled during the Neolithic. Ongoing analysis of a sediment core from a small basin mire lying approximately $250 \mathrm{~m}$ to the west of the excavations at the Braes of Ha'Breck (Farrell and Bunting, 2009) will provide more information about the availability of local timbers and potential management of woodland resources in the immediate landscape around the site.

The symbolism inherent in the use of wood and stone in buildings is well-documented in the anthropological and archaeological literature (e.g. Bloch, 1998; Noble, 2006; Parker Pearson and Ramilisonina, 1998). Nevertheless, we need to look beyond simple binary oppositions between wood and stone to explore more subtly the ways in which different materials are employed (Cummings, 2012). It is beyond the remit of the current paper to explore these wider social and theoretical implications, but the significance of this debate has the potential to be far-reaching. A more contextualised discussion of the implications of the use of timber and stone in the Neolithic of Orkney is clearly needed. 
The growing palaeoecological record suggests that both the development and decline of woodland in the Orcadian landscape occurred patchily in both space and time. This complex pattern cannot be explained by a single causal process, but is likely the result of multiple factors in different combinations in different localities. Woodland diversity apparently increased in the later Mesolithic even as its extent began to decline, and woodland persisted into the Bronze Age in some locations; just as recent archaeological finds imply a more subtle and varied use of building materials in the Neolithic than older narratives, so the palaeoecological record is revealing that the landscape within which Neolithic settlement was occurring was also diverse and dynamic. In both fields, more work remains to be done.

\section{Conclusions}

The perceived marginality of Neolithic Orkney has led to the assumption that its predominance of stone architecture was initiated by environmental necessity. In contrast, the more detailed palaeoecological analysis presented in this paper has revealed the heterogeneity of Neolithic land cover, a pattern which is supported by archaeological evidence from sites such as the Braes of Ha'Breck. The shift to building in stone during the rapid social transformations of the mid $4^{\text {th }}$ millennium BC can no longer be explained merely as a consequence of non-availability of timber.

\section{Acknowledgements}

Fieldwork at Blows Moss was financially supported by the University of Hull and some radiocarbon dates were funded under NERC Radiocarbon Dating Allocation No. 1224.0407. The work at Blows Moss formed part of Michelle Farrell's PhD, which was funded by a University of Hull Studentship. Thanks are due to Sandra Marks, Barbara Rumsby and Claire Twiddle, who provided assistance in the field, and to the landowners of Blows Moss for allowing access to the site: John Crossley, David Duncan, Charlie Nicholson and Gordon and Marlene Thomson. 
Farrell et al 2014 Journal of Archaeological Science DOI 10.1016/j.jas.2012.05.042

Excavations at the Braes of Ha'Breck are directed by Antonia Thomas and Daniel Lee of the Orkney Research Centre for Archaeology (ORCA), and have been supported by Orkney Islands Council, the Society of Antiquaries of Scotland, Orkney Archaeology Society, LEADER European Funding, Wyre Community Council, the Flaws family, Orkney Ferries and Orkney College Archaeology Department.

We are also grateful for the comments of two anonymous reviewers, which helped to improve the original draft of this manuscript.

\section{References}

Ashmore, P., 2005. Radiocarbon Report. Discovery and Excavation in Scotland (new series) $6,165-181$.

Ashmore, P., Brayshay, B.A., Edwards, K.J., Gilbertson, D.D., Grattan, J.P., Kent, M., Pratt, K.E., Weaver, R.E., 2000. Allochthonous and autochthonous mire deposits, slope instability and palaeoenvironmental investigations in the Borve Valley, Barra, Outer Hebrides, Scotland. The Holocene 10, 97-108.

Ballin Smith, B., 1994. Howe: Four Millennia of Orkney Prehistory. Society of Antiquaries of Scotland, Edinburgh.

Bartlett, D., 1983. Analysis of pollen from neighbouring locations. In: Hedges, J.W. (Ed.), Isbister: a chambered tomb in Orkney. British Archaeological Report British Series 115, 177-183.

Behre, K.E., 1981. The interpretation of anthropogenic indicators in pollen diagrams. Pollen et Spores 23, 225-245.

Bennett, K.D., 1995. Pollen Catalogue of the British Isles. Available from: [http://chrono.qub.ac.uk/pollen/pc-intro.html] (accessed 19 ${ }^{\text {th }}$ January 2012).

Bennett, K.D., 2005. Documentation for psimpoll 4.25 and pscomb 1.03: C programs for plotting pollen diagrams and analysing pollen data.

Bennett, K.D., Fossitt, J.A., Sharp, M.J., Switsur, V.R., 1990b. Holocene vegetational and environmental history at Loch Lang, South Uist, Western Isles, Scotland. New Phytologist 114, 281-298. 
Farrell et al 2014 Journal of Archaeological Science DOI 10.1016/j.jas.2012.05.042

Bennett, K.D., Simonson, W.D., Peglar, S.M., 1990a. Fire and man in post-glacial woodlands of eastern England. Journal of Archaeological Science 17, 635-642.

Berry, R.J., 2000. Orkney Nature. Academic Press, London.

Beug, H.-J., 2004. Leitfaden der Pollenbestimmung für Mitteleuropa und angrenzende Gebiete. Verlag Friedrich Pfeil, Munich.

Blackford, J.J., Edwards, K.J., Buckland, P.C., Dobney, K., 1996. Keith’s Peat Bank, Hoy: Mesolithic human impact? In: Hall, A.M. (Ed.) The Quaternary of Orkney. Quaternary Research Association, London, pp. 62-68.

Bloch, M., 1998. Why trees too, are good to think with: towards an anthropology of the meaning of life. In: Rival, L. (Ed.) The Social Life of Trees. Berg, Oxford, pp. 3955.

Bunting, M.J., 1994. Vegetation history of Orkney, Scotland; pollen records from two small basins in west Mainland. New Phytologist 128, 771-792.

Bunting, M.J., 1996. The development of heathland in Orkney, Scotland: pollen records from Loch of Knitchen (Rousay) and Loch of Torness (Hoy). The Holocene 6, 193-212.

Bunting, M.J., 2002. Detecting woodland remnants in cultural landscapes: modern pollen deposition around small woodlands in northwest Scotland. The Holocene 12, 291301.

Card, N., 2005. Assessment of the prehistoric periods. In: Downes, J., Foster, S.M., Wickham-Jones, C.R. (Eds.) The Heart of Neolithic Orkney World Heritage Site Research Agenda. Historic Scotland, Edinburgh, pp. 46-65.

Card, N., Downes, J., Sharman, P., 2006. The Knowes of Trotty, Harray, Orkney: Excavation 2005. Unpublished Data Structure Report. Orkney Archaeological Trust.

Christensen, K., 1997. Wood from fish weirs - forestry in the Stone Age. In: Pederson, L., Fischer, A., Aaby, A. (Eds.) The Danish Storebaelt since the Ice Age - man, sea and forest. A/S Storebaelt Fixed Link, Copenhagen, pp. 151-156.

Church, M.J., Dugmore, A.J., Mairs, K.A., Millard, A.R., Cook, G.T., Sveinbjarnardóttir, G., Acough, P.A., Roucoux, K.H., 2007. Charcoal production during the Norse 
Farrell et al 2014 Journal of Archaeological Science DOI 10.1016/j.jas.2012.05.042

and early Medieval periods in Eyjafjallahreppur, southern Iceland. Radiocarbon 49, 659-672.

Clark, R.L., 1982. Point count estimation of charcoal in pollen preparations and thin sections of sediments. Pollen et Spores 24, 523-535.

Cummings, V., 2012. What lies beneath: thinking about the qualities and essences of stone and wood in the chambered tomb architecture of Neolithic Britain and Ireland. Journal of Social Archaeology 12, 29-50.

Davidson, D.A., Jones, R.L., 1985. The environment of Orkney. In: Renfrew, C. (Ed.) The Prehistory of Orkney BC 4000 - AD 1000. Edinburgh University Press, Edinburgh, pp. 10-35.

Davidson, D.A., Jones, R.L., Renfrew, C., 1976. Palaeoenvironmental reconstruction and evaluation: a case study from Orkney. Transactions of the Institute of British Geographers 1, 346-361.

Dickson, C., 2000. The decline of woodland in Orkney: early Neolithic to late Iron Age. In: Nicholson, R.A., O’Connor, T.P. (Eds.) People as an Agent of Environmental Change. Oxbow, Oxford, pp. 37-44.

Dickson, J.H., 1992. North American driftwood, especially Picea (spruce), from archaeological sites in the Hebrides and Northern Isles of Scotland. Review of Palaeobotany and Palynology 73, 49-56.

Downes, J., forthcoming. The Knowes of Trotty, Orkney: Bronze Age Barrow Cemetery and Early Neolithic House.

Downes, J., Dickson, C., French, C., Hitton, P., McKinley, J.I., Scaife, R., 1994. Excavation of a Bronze Age burial at Mousland, Stromness, Orkney. Proceedings of the Society of Antiquaries of Scotland 124, 141-154.

Edwards, K.J., Ralston, I.B.M., 2003. Scotland After the Ice Age: Environment, Archaeology and History, 8000 BC - AD 1000. Edinburgh University Press, Edinburgh.

Farrell, M., 2009. The environmental context of later prehistoric human activity in Orkney, Scotland. Unpublished Ph.D. thesis. University of Hull.

Farrell, M., Bunting, M.J. 2009. Wyre Mire palaeoenvironmental investigation. Discovery and Excavation in Scotland (new series) 10, 135. 
Farrell et al 2014 Journal of Archaeological Science DOI 10.1016/j.jas.2012.05.042

Fossitt, J.A., 1996. Late Quaternary vegetation history of the Western Isles of Scotland. New Phytologist 132, 171-196.

van Geel, B., 1978. A palaeoecological study of Holocene peat bog sections in Germany and the Netherlands based on the analysis of pollen, spores and macro-and microscopic remains of fungi, algae, cormophytes and animals. Review of Palaeobotany and Palynology 25, 1-120.

van Geel, B., 2001. Non-pollen palynomorphs. In Smol, J.P., Birks, H.J.B., Last, W.M. (Eds.) Tracking Environmental Change Using Lake Sediments. Volume 3: Terrestrial, Algal and Siliceous Indicators. Kluwer Academic Publishers, Dordrecht, pp. 99-119.

van Geel, B., Bohncke, S.J.P., Dee, H., 1981. A palaeoecological study of an upper late glacial and Holocene sequence from "De Borchert," the Netherlands. Review of Palaeobotany and Palynology 31, 367-448.

van Geel, B., Hallewas, D.P., Pals, J.P., 1983. A late Holocene deposit under the Westfriese Zeedijk near Enkhuizen (Prov. of Nord-Holland, The Netherlands): palaeoecological and archaeological aspects. Review of Palaeobotany and Palynology 33, 269-335.

van Geel, B., Coope, G.R., van der Hammen, T., 1989. Palaeoecology and stratigraphy of the lateglacial type section at Usselo (The Netherlands). Review of Palaeobotany and Palynology 60, 25-129.

van Geel, B., Buurman, J., Brinkkemper, O., Schelvis, J., Aptroot, A., van Reenen, G., Hakbijl, T., 2003. Environmental reconstruction of a Roman Period settlement site in Uitgeest (The Netherlands), with special reference to coprophilous fungi. Journal of Archaeological Science 30, 873-883.

Hunter, J., 2007. Excavations at Pool, Sanday: multi-period settlement from Neolithic to Late Norse times. The Orcadian Ltd, Kirkwall.

Jones, R.L., 1975. Environment - pollen. In: Hedges, J.W. (Ed.) Excavation of two Orcadian burnt mounds at Liddle and Beaquoy. Proceedings of the Society of Antiquaries of Scotland 106, 84-88.

Jones, R.L., 1979. Vegetational studies. In: Renfrew (Ed.) Investigations in Orkney. Society of Antiquaries of London, London, pp. 21-28. 
Farrell et al 2014 Journal of Archaeological Science DOI 10.1016/j.jas.2012.05.042

Jowsey, P.C., 1966. An improved peat sampler. New Phytologist 65, 245-248.

Keatinge, T.H., Dickson, J.H., 1979. Mid-Flandrian changes in vegetation on Mainland Orkney. New Phytologist 82, 585-612.

Lee, D.H.J., Thomas, A., forthcoming. Life on a small island in the $4^{\text {th }}$ millennium BC. Recent excavations at the Early Neolithic settlement at Ha'Breck, Wyre, Orkney. Current Archaeology.

Lee, D.H.J., Thomas, A., in prep. The Braes of Ha'Breck, Wyre, Orkney: Excavation 2009-2011. Unpublished Data Structure Report. Orkney Research Centre for Archaeology (ORCA).

Lee, D.H.J., Woodward, N.L., in prep. Mesolithic occupation at Links House, Stronsay, Orkney c.7000 cal BC: The first structural evidence for the Northern Isles of Scotland.

Maher, L.J. Jr., 1972. Nomograms for computer 0.95 confidence limits of pollen data. Review of Palaeobotany and Palynology 13, 85-93.

McQuade, M., O' Donnell, L., 2007. Late Mesolithic fish traps from the Liffey Estuary, Dublin. Antiquity 81, 569-584.

Mighall, T.M., Cortizas, A.M., Biester, H., Turner, S.E., 2006. Proxy climate and vegetation changes during the last five millennia in NW Iberia: pollen and nonpollen palynomorph data from two ombrotrophic peat bogs in the North West Iberian Peninsula. Review of Palaeobotany and Palynology 141, 203-223.

Miles, M., 2008. A trial excavation on a Neolithic settlement site at Green, Isle of Eday, August 2007. Unpublished report. British Excavation Volunteers \& Archaeological Research Society (BEVARS).

Miles, M., 2010. A trial excavation on a Neolithic settlement site at Green, Isle of Eday, August 2009. Unpublished report. British Excavation Volunteers \& Archaeological Research Society (BEVARS).

Moar, N.T., 1969. Two pollen diagrams from the Mainland, Orkney Islands. New Phytologist 68, 201-208.

Moore, P.D., Webb, J.A., Collinson, M.E., 1991. Pollen Analysis. Blackwell Scientific Publications, Oxford. 
Farrell et al 2014 Journal of Archaeological Science DOI 10.1016/j.jas.2012.05.042

Noble, G., 2006. Neolithic Scotland: Timber, Stone, Earth and Fire. Edinburgh University Press, Edinburgh.

O'Connor, T., Bunting, M.J., 2009. Environmental change in an Orkney wetland: plant and molluscan evidence from Quoyloo Meadow. In: Allen, M.J., O'Connor, T., Sharples, N.M. (Eds.) Land and People: Papers in Memory of John G. Evans. Oxbow, Oxford, pp. 161-168.

Parker Pearson, M., Ramilisonina., 1998. Stonehenge for the ancestors: the stones pass on the message. Antiquity 72, 308-326.

Renfrew, C., 1985. The Prehistory of Orkney BC 4000 - 1000 AD. Edinburgh University Press, Edinburgh.

Richards, C., 2003. Excavation of the early Neolithic settlement at Wideford, Mainland, Orkney. Unpublished structures report for Historic Scotland. University of Manchester.

Richards, C., 2005. Dwelling Among the Monuments: the Neolithic village of Barnhouse, Maeshowe passage grave and surrounding monuments at Stenness, Orkney. McDonald Institute for Archaeological Research, Cambridge.

Richards, C., Downes, J., Card, N., Carruthers, M., Jones, S., Challands, A., Jones, R., 2001. The Cuween-Wideford Landscape Project, Mainland, Orkney: Fieldwork 2000. Unpublished Data Structure Report prepared for Historic Scotland. University of Glasgow.

Richards, C., Jones, R., forthcoming. Neolithic house societies in Orkney: investigations at Crossiecrown, Stonehall and Wideford Hill, Mainland, Orkney.

Ritchie, A., 1983. Excavation of a Neolithic farmstead at Knap of Howar, Papa Westray, Orkney. Proceedings of the Society of Antiquaries of Scotland 113, 40-121.

Ritchie, A., 1985. The first settlers. In: Renfrew, C. (Ed.) The Prehistory of Orkney BC 4000 - AD 1000. Edinburgh University Press, Edinburgh, pp 36-53.

Ritchie, A., 1995. Prehistoric Orkney. B.T. Batsford, London.

Robertson, J.R.,Woodward N.L., 2007. Long Howe, Tankerness, Orkney: Data Structure Report. Unpublished report, Orkney Research Centre for Archaeology (ORCA). 
Farrell et al 2014 Journal of Archaeological Science DOI 10.1016/j.jas.2012.05.042

Schofield, J.E., Edwards, K.J., 2011. Grazing impacts and woodland management in Eriksfjord: Betula, coprophilous fungi and the Norse settlement of Greenland. Vegetation History and Archaeobotany 20, 181-197.

Simpson, I.A., Vésteinsson, O., Adderley, W.P., McGovern, T.H., 2003. Fuel resource utilisation in landscapes of settlement. Journal of Archaeological Science 30, 1401-1420.

Stockmarr, J., 1971. Tablets with spores used in absolute pollen analysis. Pollen et Spores 13, 615-621.

Stuiver, M., Reimer, P.J., 1993. Extended ${ }^{14} \mathrm{C}$ database and revised CALIB $3.0{ }^{14} \mathrm{C}$ age calibration program. Radiocarbon 35, 215-230.

Sugita, S., 1994. Pollen representation of vegetation in Quaternary sediments: theory and method in patchy vegetation. Journal of Ecology 82, 881-897.

Thomas, A., Lee, D.H.J., 2008. The Braes of Ha'Breck, Wyre, Orkney: Excavation 2007. Unpublished Data Structure Report. Orkney Archaeological Trust.

Thomas, A., Lee, D. H.J., 2010. The Braes of Ha'Breck, Wyre, Orkney: Excavation 2008. Unpublished Data Structure Report (ORCA Project No 204). Orkney Research Centre for Archaeology (ORCA).

Tipping, R., 1994. The form and fate of Scotland's woodlands. Proceedings of the Society of Antiquaries of Scotland 124, 1-54.

Tisdall, E.W., McCulloch, R.D., Sanderson, D.C., Simpson, I.A., Woodward, N.L., in prep. First peopling of the North Atlantic Fringes: palaeoenvironmental evidence from Orkney, Scotland. Quaternary International.

Traill, W., Kirkness, W., 1937. Hower, a prehistoric structure on Papa Westray, Orkney. Proceedings of the Society of Antiquaries of Scotland 71, 309-322.

Troels-Smith, J., 1955. Characterisation of unconsolidated sediments. Danmarks Geologiske Undersøgelse Series IV 3, 38-73.

de la Vega-Leinert, A.C., Keen, D.H., Jones, R.L., Wells, J.M., Smith, D.E., 2000. MidHolocene environmental changes in the Bay of Skaill, Mainland Orkney, Scotland: an integrated geomorphological, sedimentological and stratigraphical study. Journal of Quaternary Science 15, 509-528. 
Farrell et al 2014 Journal of Archaeological Science DOI 10.1016/j.jas.2012.05.042

de la Vega-Leinert, A.C., Smith, D.E., Jones, R.L., 2007. Holocene coastal environmental changes on the periphery of an area of glacio-isostatic uplift: an example from Scapa Bay, Orkney, UK. Journal of Quaternary Science 22, 755-772.

Woodward, N.L., 2012. Tanged flint points and their contribution to understanding the early post-glacial settlement of northern Scotland. Unpublished Ph.D. thesis. University of Aberdeen.

Woodward, N.L., Lee D.H.J., Wickham-Jones C., in prep. Links House, Stronsay, Orkney: a tanged flint point in the context of Mesolithic activity in northern Scotland. 
Farrell et al 2014 Journal of Archaeological Science DOI 10.1016/j.jas.2012.05.042

Table 1 Radiocarbon age estimates from Blows Moss

\begin{tabular}{lllllll}
\hline $\begin{array}{l}\text { Laboratory } \\
\text { code }\end{array}$ & $\begin{array}{l}\text { Depth } \\
(\mathbf{c m})\end{array}$ & $\begin{array}{l}\mathbf{1 4}^{\mathbf{1 4}} \mathbf{C} \text { age } \\
\mathbf{B P}(\mathbf{1} \boldsymbol{\sigma})\end{array}$ & AMS $\boldsymbol{\delta}^{\mathbf{1 3}} \mathbf{C}$ & $\begin{array}{l}\text { Calibrated } \\
\text { age range BP } \\
(\mathbf{2} \boldsymbol{\sigma})\end{array}$ & $\begin{array}{l}\text { Calibrated } \\
\text { calendar age } \\
\text { range (2 } \boldsymbol{\sigma})\end{array}$ & $\begin{array}{l}\text { Midpoint of } \\
\text { calibrated calendar } \\
\text { age range }\end{array}$ \\
\hline SUERC-17186 & 177 & $4864 \pm 38$ & -28.2 & $5660-5482$ & $3710-3532 \mathrm{BC}$ & $3621 \mathrm{BC}$ \\
\hline SUERC-17185 & 353 & $6402 \pm 39$ & -29.8 & $7419-7268$ & $5469-5318 \mathrm{BC}$ & $5394 \mathrm{BC}$ \\
\hline UBA-17046 & 517 & $7916 \pm 43$ & -36.0 & $8977-8602$ & $7027-6652 \mathrm{BC}$ & $6840 \mathrm{BC}$ \\
\hline
\end{tabular}


Farrell et al 2014 Journal of Archaeological Science DOI 10.1016/j.jas.2012.05.042

Table 2 Description of local pollen assemblage zones at Blows Moss

\begin{tabular}{|c|c|}
\hline Zone/subzone & Description \\
\hline \multirow{3}{*}{$\begin{array}{l}\text { BM-3/BM-3a } \\
155-177 \mathrm{~cm} \\
\text { c. } 3260-3610 \text { cal. BC }\end{array}$} & Well-humified peat; varying proportions of graminoid and herbaceous plant fragments \\
\hline & $\begin{array}{l}\text { AP declines to } c .10 \% \text {; pteridophyte spores } c .40 \% \text {; herbaceous taxa } c .50 \% \text {; Plantago } \\
\text { lanceolata, Rumex undiff. and Artemisia-type present }\end{array}$ \\
\hline & $\begin{array}{l}\text { Sordaria-type ascospores } c .15 \% \text {; Podospora-type and Sporomiella-type present at low } \\
\text { frequencies }\end{array}$ \\
\hline \multirow{4}{*}{$\begin{array}{l}\text { BM-2 } \\
177-353 \mathrm{~cm} \\
\text { c. } 3610-5390 \text { cal. BC }\end{array}$} & Well-humified peat; varying proportions of graminoid and herbaceous plant fragments \\
\hline & $\begin{array}{l}\text { AP (mainly Betula and Corylus avellana-type) declines to } c .30 \% \text {; pteridophye spores } c \text {. } \\
15 \% \text {; herbaceous taxa dominate at } c .50 \% \text {; Plantago lanceolata and Artemisia-type } \\
\text { sporadically present at low frequencies }\end{array}$ \\
\hline & Low quantities of microscopic charcoal present towards top of zone \\
\hline & Sordaria-type ascospores $c .5 \%$; Podospora-type occasionally present at low frequencies \\
\hline \multirow{4}{*}{$\begin{array}{l}\text { BM-1/BM-1c } \\
353-461 \mathrm{~cm} \\
\text { c. } 5390-6350 \text { cal. BC }\end{array}$} & Fine organic lake mud with relatively high silt content \\
\hline & $\begin{array}{l}\text { AP increases to c. } 70 \% \text { (Corylus avellana-type } 30-40 \% \text { ); pteridophyte spores } 5-10 \% \text {; } \\
\text { herbaceous taxa c. } 20 \% \text {; aquatic taxa present at lower frequencies }\end{array}$ \\
\hline & Microscopic charcoal present $\left(c .0 .7 \mathrm{~cm}^{2} \mathrm{~cm}^{-3}\right)$ in lower half of subzone \\
\hline & Sordaria-type ascospores sporadically present at low frequencies \\
\hline \multirow{4}{*}{$\begin{array}{l}\mathrm{BM}-1 / \mathrm{BM}-1 \mathrm{~b} \\
461-533 \mathrm{~cm} \\
\text { c. } 6350-6980 \mathrm{cal} . \mathrm{BC}\end{array}$} & Fine organic lake mud with relatively high silt content \\
\hline & $\begin{array}{l}\text { AP declines to } c .50 \% \text { (mainly Corylus avellana-type but Betula also declines slightly); } \\
\text { pteridophyte spores } 15-20 \% \text {; Poaceae increases to } c .2 \% \text {, Cyperaceae to } c .15 \% \text { and } \\
\text { Filipendula to } c .4 \% \text {; aquatic taxa (Myriophyllum spicatum and Myriophyllum } \\
\text { alterniflorum) present }\end{array}$ \\
\hline & Microscopic charcoal low but consistently present \\
\hline & Sordaria-type ascospores present at low frequencies above $470 \mathrm{~cm}$ \\
\hline \multirow{3}{*}{$\begin{array}{l}\text { BM-1/BM-1a } \\
533-645 \mathrm{~cm} \\
\text { c. } 6980-7970 \text { cal. BC }\end{array}$} & Fine organic lake mud with relatively high silt content \\
\hline & $\begin{array}{l}\text { AP rises from } c .40 \% \text { at base of subzone to a maximum of } c .80 \% \text { (Corylus avellana-type } \\
\text { and Betula dominant); pteridophyte spores decline towards top of subzone; Cyperaceae ( } c \text {. } \\
5 \% \text { ) and Phragmites-type (c. } 10 \%) \text { are the dominant herbaceous taxa; Empetrum nigrum } c \text {. } \\
8 \% \text { at base of subzone; aquatic taxa including Myriophyllum spicatum present throughout }\end{array}$ \\
\hline & Microscopic charcoal present at top of subzone \\
\hline
\end{tabular}


Farrell et al 2014 Journal of Archaeological Science DOI 10.1016/j.jas.2012.05.042

\section{Table captions}

Table 1 Radiocarbon age estimates from Blows Moss

Table 2 Description of local pollen assemblage zones at Blows Moss 
Farrell et al 2014 Journal of Archaeological Science DOI 10.1016/j.jas.2012.05.042

\section{Figure captions}

Figure 1 Location maps showing (a) the location of Orkney in Scotland; (b) location of palaeocological sites mentioned in the text $(\mathrm{BM}=$ Blows Moss; $\mathrm{BR}=$ Burnt of Rusht; $\mathrm{BS}$ = Bay of Skaill; GM = Glims Moss; Ho = Hobbister; KPB = Keith's Peat Bank; LK = Loch of Knitchen; LM = Lesliedale Moss; LT = Loch of Torness; MB = Mill Bay; QM = Quoyloo Meadow; SB = Scapa Bay; SM = Spretta Meadow; WB = Whaness Burn); (c) location of archaeological sites mentioned in the text $(\mathrm{BH}=$ Braes of Ha'Breck; $\mathrm{Gr}=$ Green; Ho = Howe; KH = Knap of Howar; KT = Knowes of Trotty; Mo = Mousland; Po $=$ Pool; $\mathrm{St}=$ Stonehall; $\mathrm{Wi}=$ Wideford $)$.

Figure 2 Blows Moss (a) Percentages of pollen and spores of selected taxa; (b) Pollen and spore concentrations of selected taxa

Figure 3 Primary and secondary woodland decline dates from both previously published and new (Farrell, 2009) radiocarbon dated pollen profiles

Figure 4 Site plan of the early Neolithic settlement at Braes of Ha'Breck, Wyre 
Figure 1 Location maps showing (a) the location of Orkney in Scotland; (b) location of palaeocological sites mentioned in the text $(\mathrm{BM}=$ Blows Moss; $\mathrm{BR}=$ Burnt of Rusht; $\mathrm{BS}$ = Bay of Skaill; GM = Glims Moss; Ho = Hobbister; KPB = Keith's Peat Bank; LK = Loch of Knitchen; LM = Lesliedale Moss; LT = Loch of Torness; MB = Mill Bay; QM = Quoyloo Meadow; SB = Scapa Bay; SM = Spretta Meadow; WB = Whaness Burn); (c) location of archaeological sites mentioned in the text $(\mathrm{BH}=$ Braes of Ha'Breck; $\mathrm{Gr}=$ Green; Ho = Howe; KH = Knap of Howar; KT = Knowes of Trotty; Mo = Mousland; Po $=$ Pool; $\mathrm{St}=$ Stonehall; $\mathrm{Wi}=$ Wideford $)$.

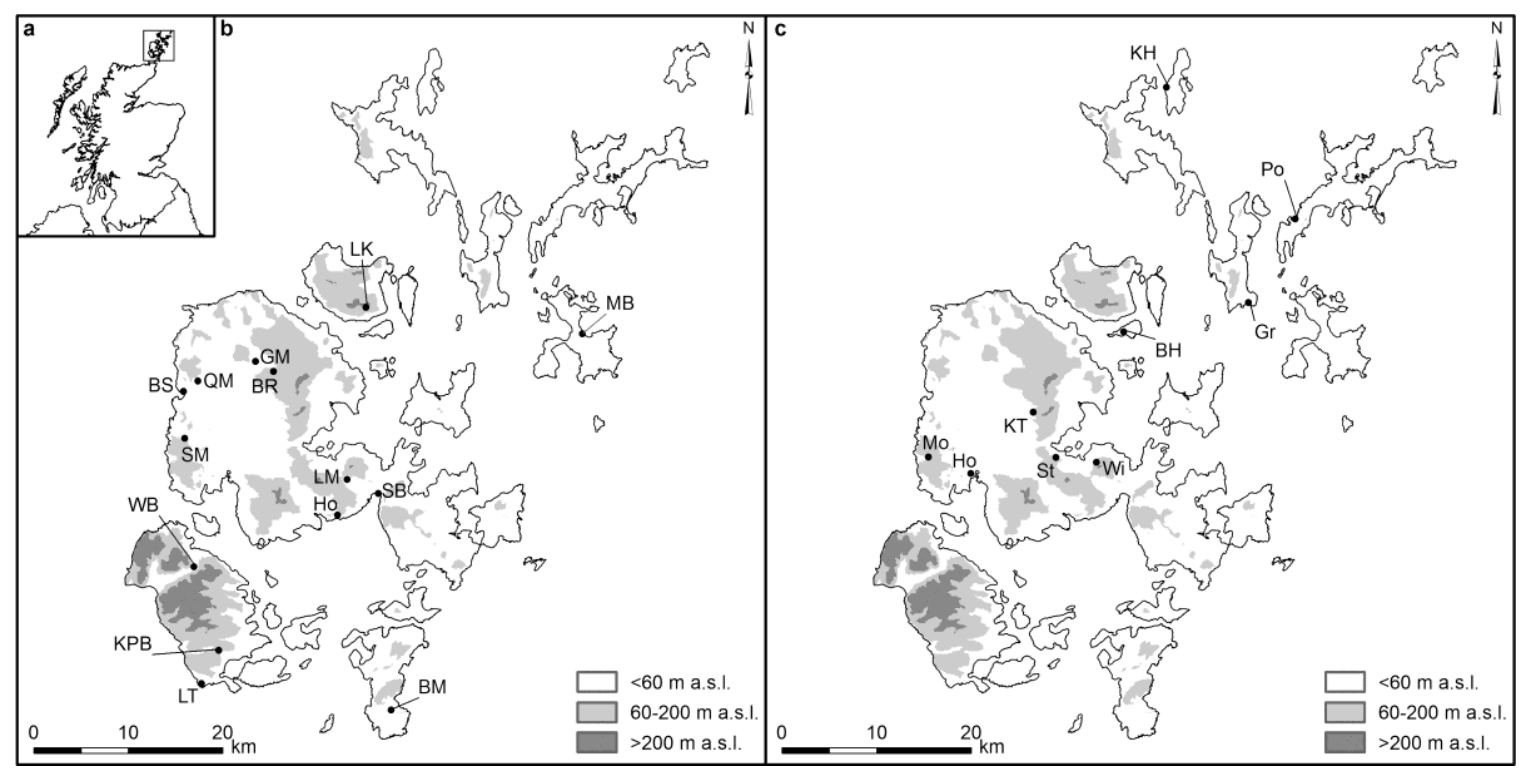


Figure 2 Blows Moss (a) Percentages of pollen and spores of selected taxa; (b) Pollen and spore concentrations of selected taxa
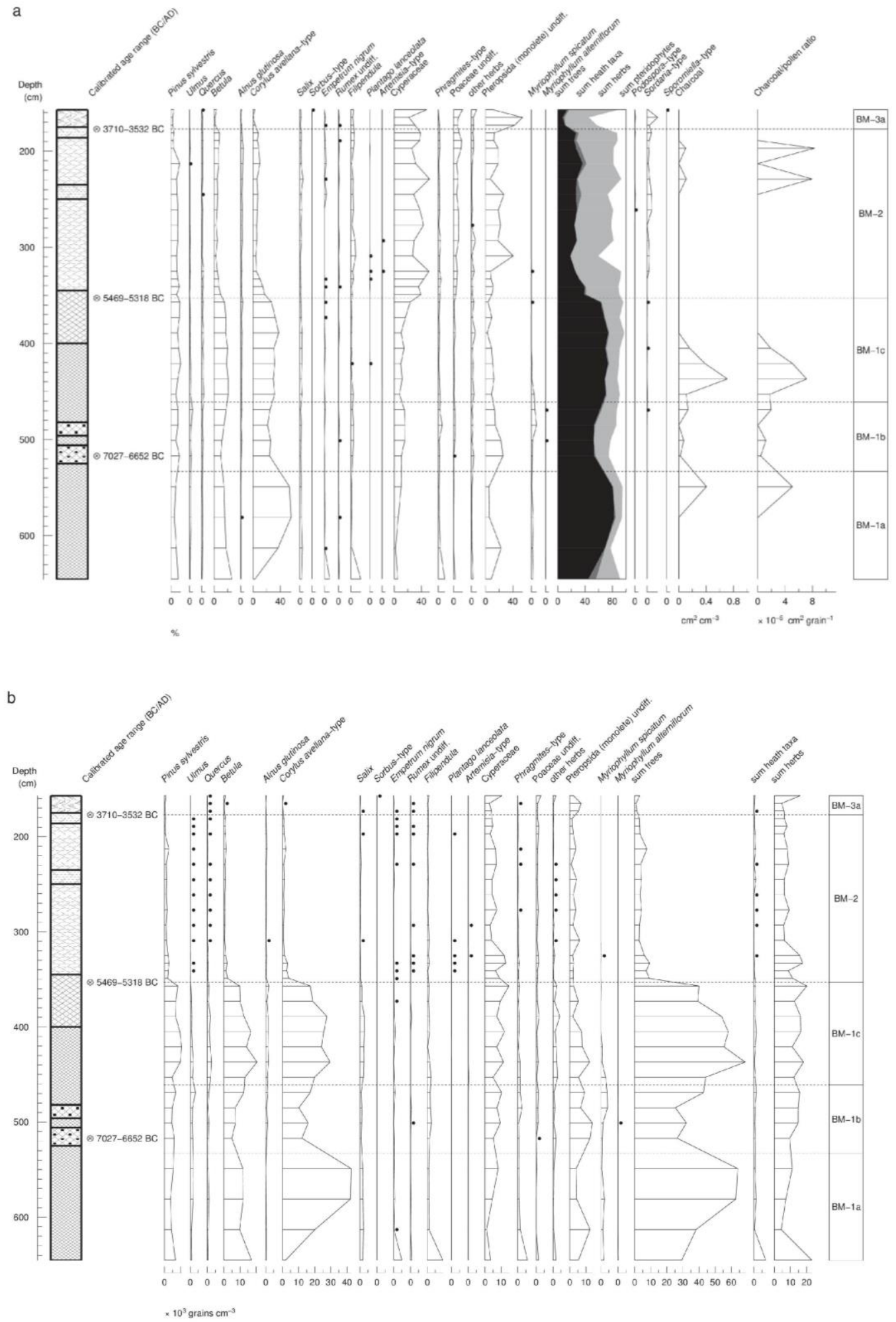
Figure 3 Primary and secondary woodland decline dates from both previously published and new (Farrell, 2009) radiocarbon dated pollen profiles

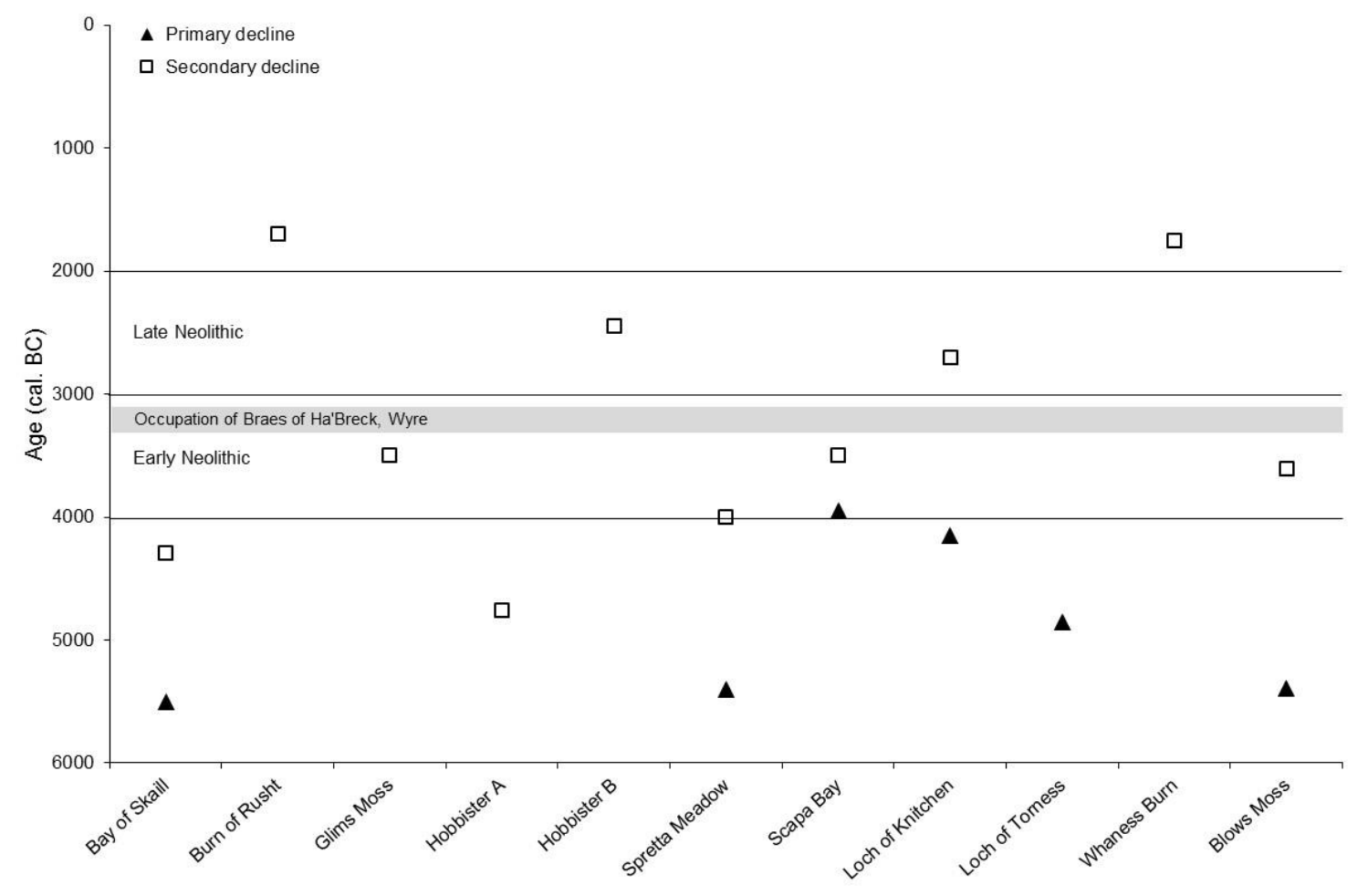


Farrell et al 2014 Journal of Archaeological Science DOI 10.1016/j.jas.2012.05.042

Figure 4 Site plan of the early Neolithic settlement at Braes of Ha'Breck, Wyre

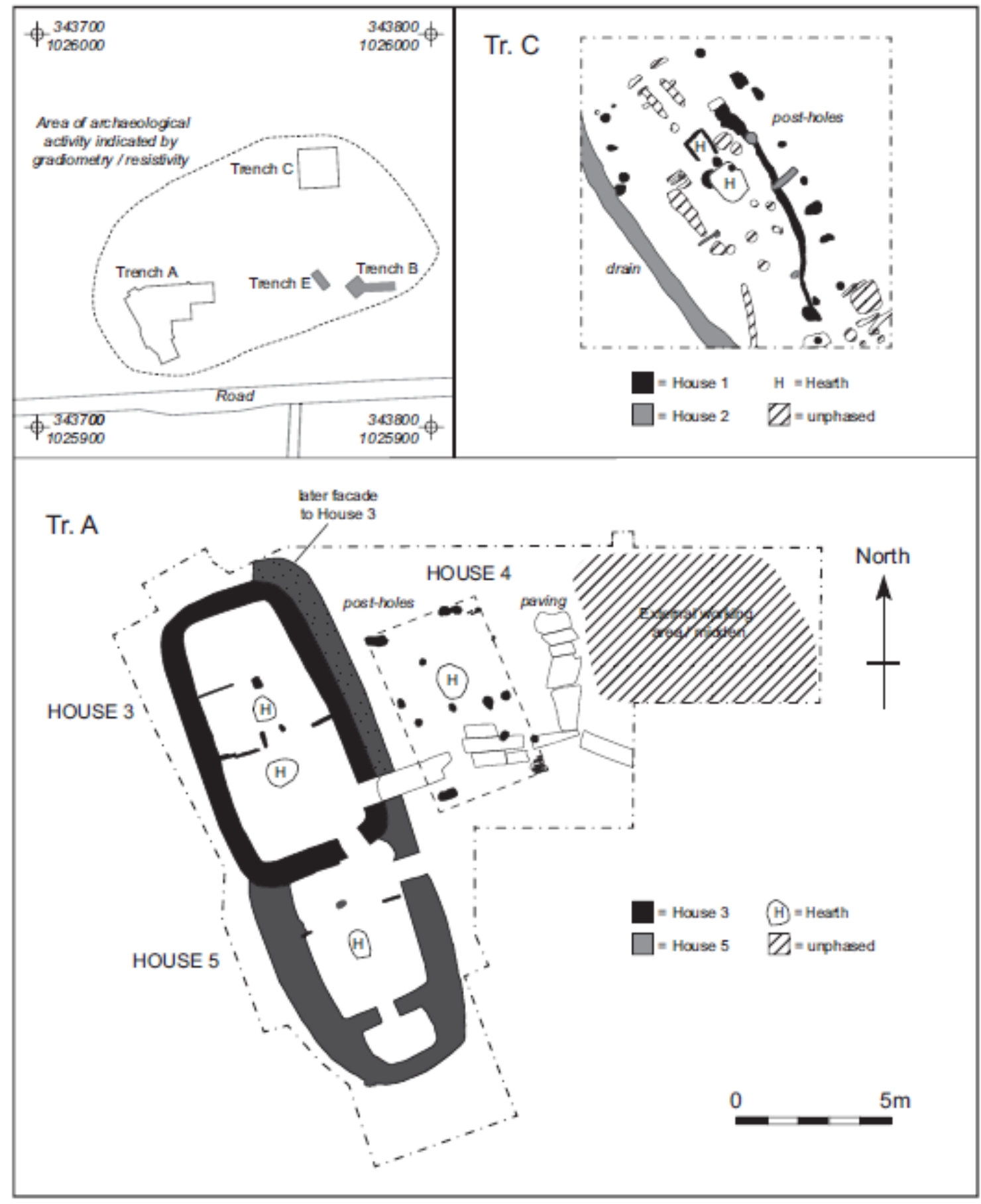

